\title{
Koroonaviiruse SARS-CoV-2 algusfaasi vastukaja (sotsiaal)meedias
}

\author{
Maris Kuperjanov \\ Eesti Kirjandusmuuseumi folkloristika osakonna arhivaar-referent \\ maris.kuperjanov@folklore.ee
}

\begin{abstract}
Teesid: Artiklis on vaatluse all uue koroonaviiruse puhangu algusperiood ning reageeringud viiruseteemalistele uudistele meediakommentaarides ja sotsiaalmeedias. Kuigi pandeemia on artikli koostamise ajalgi alles algusjärgus ning teadmised viirusest SARS-CoV-2 ja selle põhjustatavast haigusest COVID-19 täienevad iga päevaga, on suur infotulv ja puhangu kiire eskaleerumine olnud viljakaks pinnaseks temaatilise folkloori levikule juba alates esmasest viirusest teadasaamisest. Saab jälgida nalju ja meeme, nii inimlikust veast või teadmatusest tingitud väärinfo kui ka pahatahtlike eesmärkidega valeuudiste levikut, vandenõuteooriaid ja muid narratiive, mis tihti epideemiatega kaasas käivad, kusjuures nende mõju ühiskonnale võib tihtipeale olla halvavamgi kui haigus ise. Mitmed kasutusel olevad motiivid ja süžeed on ammutuntud ja universaalsed, kerkides sarnaste olukordade tekkimisel ühtviisi esile nii Eestis kui ka mujal maailmas.
\end{abstract}

Märksõnad: koroonaviirus, meemid, rahvatervis, sotsiaalmeedia, vandenõuteooriad

Käesolev artikkel on empiiriline uurimus viiruspuhangu tekkele, uue seni inimesel kirjeldamata viiruse tuvastamisele ja selle kajastustele järgnenud esmastest reaktsioonidest uudistekommentaarides ja sotsiaalmeedias. Vaatluse all olid viiruspuhangust teadasaamisele järgneva kuu uudised mitmetes meediakanalites, 2020. aasta jaanuari alguses peamiselt BBC News, Channel 4 News, Deutsche Welle, Global News, Arirang jt, kuid peagi hakkas tihedamalt ilmuma uudiseid ja nende tagasisidet ka Eesti meediaväljaannetes, nt Postimees, Delfi, Eesti Ekspress. Et meedias ja sotsiaalmeedias toimuvat objektiivsemalt hinnata, jälgisin Maailma Terviseorganisatsiooni esmaseid teavitusi haiguspuhangust ja hilisemaid igapäevaseid situatsiooniraporteid, samuti meditsiiniajakirjades Lancet ja JAMA ilmuvaid esmaseid ülevaateid ja artikleid uuest viirusest. Eesti Kirjandusmuuseumi folkloristika osakonna arhiivi EFITA koroonaviiruse teemaliste meemide kogumiseks kasutasin puhangu algul eelkõige ära oma tutvusringkonda ning palusin sotsiaalmeedias kohatud meeme endale edastada. 
Juba esimese kuu jooksul võis täheldada populaarsemate teemade esiletõusu ja mõne puhul juba ka tagasilangust, mida lähemalt tutvustan.

Interneti uurimine, sealhulgas internetimeditsiini ja meemide uurimine on olnud viimastel kümnenditel populaarne (Blank 2009; Goldstein 2004; Shifman 2014; Kõiva 2010; Kõiva 2014; Voolaid 2014 jt), kuid enamasti on käsitletud teistlaadi haiguseid ja juhtumeid. Kiire levikuga viiruspuhang, mis paari kuuga on suutnud esimestest tuvastatud juhtudest kasvada üleilmseks pandeemiaks, annab võimaluse jälgida reaalajas puhangu eskaleerumisega kaasnevaid emotsioone ja kogu maailmas aset leidvaid kiireid muutusi.

31. detsembril 2019 informeeriti Maailma Terviseorganisatsiooni (WHO) esimestest teadmata etioloogiaga kopsupõletikujuhtudest Hiinas Hubei provintsi Wuhani linnas. Haiguspuhangut seostati linna mereandideturuga, kus kaubeldi ka illegaalsete loomadega. Turg suleti ja desinfitseeriti 1. jaanuaril, kuid 3. jaanuaril oli Hiina võimude teatel sarnase teadmata etioloogiaga kopsupõletikus patsiente juba 44 (WHO 2020a). Teised hingamisteede patogeenid nagu gripp, linnugripp, adenoviirus, SARS-CoV, MERS-CoV välistati ning 7. jaanuaril isoleeriti uut tüüpi koroonaviirus (2019-nCoV, alates 11. veebruarist 2020 ametliku nimega viirus SARS-CoV-2 ning selle põhjustatav haigus COVID-19). Koroonaviirused on suur perekond viiruseid, mis põhjustavad imetajate ja lindude haigestumisi, seni teadaolevalt olid kuus neist võimelised nakatama ka inimesi, põhjustades nii kergeid külmetushaigusi kui ka raskemaid haigusi nagu SARS (raskekujuline äge respiratoorne sündroom, aastatel 2002-2003 jõudis haiguspuhang 17 riiki ning tõi kaasa 8098 ametlikku juhtu, millest 774 lõppesid surmaga) ja MERS (Lähis-Ida respiratoorne sündroom, esimest korda raporteeriti Saudi-Araabias aastal 2012, seni teadaolev letaalsus ca 34\%). Täpsem uurimine on näidanud, et SARS-CoV oli tõenäoliselt pärit nahkhiirtelt ning jõudis inimeseni väikeste kärpkaslaste tsiibetite kaudu ning MERS-CoV nakkus saadakse otsese või kaudse kontakti teel dromedaridelt ehk üksküürkaamelitelt. SARSCoV-2 on uus tüvi, mida pole seni inimestel kirjeldatud, puhangu algusfaasis arvati, et tõenäoliselt on see inimesele kandunud nahkhiirtelt soomuslooma kaudu. Enamik inimesi põeb seda kergelt, kuid rasketel juhtudel võib viirus põhjustada kopsupõletikku, raskekujulist ägedat respiratoorset sündroomi ja hulgiorganpuudulikkust, millele võib järgneda ka surm.

12. jaanuaril jagasid Hiina võimud 2019-nCoV geneetilist järjestust WHO ja teiste riikidega, see võimaldas kiirelt välja arendada spetsiifilised reaalaja polümeraasi ahelreaktsiooni (RT-PCR) diagnostilised testid. WHOle saabunud Hiina ametliku informatsiooni kohaselt 11. ja 12. jaanuaril oli selleks ajaks Hiinas diagnoositud 41 nakatunut, mitmed neist raskes seisus ning teatati ka esimese kaasuvate haigustega patsiendi surmast. Kinnitatud 41 juhul olid patsientidel sümptomid ilmnenud ajavahemikus 8. detsembrist 2019 kuni 2. jaanuarini 2020 
ning Hiina võimude teatel uusi juhtumeid 12. jaanuariks ei olnud tuvastatud. Selleks ajaks ei olnud ka ametlikke teateid meditsiinipersonali haigestumise kohta ega kinnitust inimeselt inimesele levimisest, nakkusjuhtusid seostati Wuhani mereandideturuga (WHO 2020b).

Samal päeval diagnoositi aga uus koroonaviirus häiret andnud arstil Li Wenliangil, seega leidis ka avalikkuse ees kinnitust haiglatingimustes inimeselt inimesele kandunud nakkus. Dr Li Wenliang oli esimene arst, kes hoiatas oma koolikaaslasi võimaliku uue viiruse eest WeChati vahendusel 30. detsembril, mil tema haiglas oli isolatsioonis seitse SARSilaadsete sümptomitega patsienti (Wenliang). Info levis kiiresti ning kohalikud võimuesindajad kuulasid tema ja teised vestlusrühma kuulunud arstid üle, süüdistades neid sotsiaalse korra häirimises ning väärinformatsiooni levitamises (Xiong \& Gan 2020). Dr Li Wenliang suri viirusest tingitud haigusse 7. veebruaril, see põhjustas lisapingeid Hiina kommunistliku režiimi vastu ning sõnavabaduse nõudmist ja süüdistusi, et arstide hoiatusi kohe algul tõsiselt võttes oleks võinud viiruspuhangu kiiremini kontrolli alla saada.

Ülioluline oli viiruspuhangu ajastus - 10. jaanuarist 18. veebruarini oli Hiina kalendri aastavahetusperiood, mida võib pidada tänapäeval maailma suurimaks rahvasterände põhjustajaks. Hinnanguliselt võetakse Hiina uusaastapidustuste perioodil ette kolm miljardit reisi nii Hiinas kui ka kogu maailmas, ning kahtlemata oli rändel viiruse kiire ja laialdase leviku seisukohalt suur tähtsus.

Niipea kui 2019-nCoV spetsiifilised RT-PCR testid välja töötati ja testima asuti, teatati ka esimestest laboratoorselt kinnitatud juhtudest väljaspool Hiinat - 13. jaanuaril Tais, 15. jaanuaril Jaapanis ja 20. jaanuaril LõunaKoreas, kõik seostatavad Wuhaniga. Esimesest kinnitatud juhtumist PõhjaAmeerikas teatati 23. jaanuaril ning Euroopas ja Austraalias 25. jaanuaril 2020.

Hiina võimud otsustasid 23. jaanuaril sulgeda viiruse edasise leviku tõkestamiseks epitsentri Wuhani ning 24. jaanuaril veel kaksteist Hubei provintsi linna. Siiski jõudis enne Wuhani linna sulgemist hinnanguliselt viis miljonit inimest sealt lahkuda ning seetõttu võis eeldada viiruse laialdasemat levikut. Kuid kahtlemata aitasid kehtestatud drakoonilised meetmed viiruse levikut aeglustada ning võimaldasid anda teistele riikidele ettehoiatuse.

Tuntud meditsiiniajakirjades (The Lancet, JAMA jne) hakati avaldama kiirelt täienevat informatsiooni ja teadusartikleid, loodi spetsiaalsed viiruseteemalise info keskused (https://www.thelancet.com/coronavirus ja https:// jamanetwork.com/journals/jama/pages/coronavirus-alert, mõlemad kontrollitud 30.03.2020), kus on võimalik jälgida tõenduspõhist informatsiooni. Maailma Terviseorganisatsioon lõi samuti viirusele pühendatud veebilehe (WHO 2020c), mis tutvustab viirust ja kaitsemeetmeid ning avaldab aruandeid olukorrast. Johns Hopkinsi ülikool hakkas 20. jaanuarist jälgima ning visualiseerima 
haiguste tõrje ja ennetamise keskustele (CDC) ja Maailma Terviseorganisatsioonile laekunud ametlikku infot uue koroonaviiruse juhtude kohta kogu maailmas. WHO pidas viiruspuhangule pühendatud koosolekuid, kuid alles 30. jaanuaril kuulutati välja rahvusvahelise tähtsusega rahvatervise-alane hädaolukord (WHO 2020d). Ametlike teadete kohaselt oli selle otsuse ajaks 7736 juhtu Hiinas (sealhulgas teatatud 170 surma) ja lisaks 82 nakatunut 18 riigis. WHO sõnul polnud hädaolukorra väljakuulutamiseks olukord Hiinas, vaid võimalus, et uus viirus võib kujutada endast suurt ohtu, levides vaesematesse ja nõrgema tervishoiusüsteemiga riikidesse.

\section{Reaktsioonid infovoo suurenemisele meedias}

Hiinast ning teistes viirusega haaratud maadest tuleva infovoo pidev suurenemine jaanuaris tõi sellekohase teabe aina rohkem nähtavaks ka meedias ning sotsiaalmeedias. Artiklite, postituste, videote arv ning kommentaarid ja vastukaja neile suurenes märkimisväärselt. Nagu varasemate epideemiate ja pandeemiate puhul, lõi viirus ja selle kajastus viljaka pinnase naljade, internetimeemide, juttude ja vandenõuteooriate tekkeks.

Meemid erinevad oma olemuselt ikoonilistest piltidest ja viraalsetest postitustest, mis levides oluliselt ei muutu (Denisova 2019: 8). Viiruseteate peale hakkasid levima mõlemad, nii temaatilised modifitseeritud meemid kui ka staatilisemad elemendid, nt viraalsed tekstid, pildid, loosungid, laulud. Lai valik meemigeneraatoreid ja -keskkondi loob hea võimaluse meeme kerge vaevaga luua, kopeerida, muuta ja jagada, levikut kiirendavad omakorda sotsiaalmeediaplatvormid. Paljusid tuntud ja suurt kasutust leidvaid meemipõhju kohandatakse parasjagu aktuaalsele sündmusele ja need on pidevas kasutuses (telesarjast "Sõbrad" tuntud Joey viivitatud reaktsioon (Joey's Delayed Reaction), filmist "Kontorirotid" pärit väga levinud That would be Great (see oleks tore), katkuga seostuv The Plague Doctor, kui nimetada mõnda levinud tüüpi internetimeeme ja viraalseid fenomene dokumenteerivast ja kirjeldavast veebikeskkonnast Know Your Meme1), kuid luuakse ka uusi spetsiifilisemaid meeme ja viraalseid postitusi, mis kirjeldavad konkreetset sündmust või lugu.

Jälgisin nii mitmetele välismeediakanalite kui ka Eesti meedia uudiseid, kommentaare, reaktsioone ja meeme. Päris suures osas olid viiruse algusfaasis ehk 2020. aasta jaanuaris minuni jõudnud meemid ja viraalsed postitused pigem universaalsed, vahel kohalikku keelde tõlgitud, vahel veidi kohalikesse oludesse kohandatud, näitena kasutajate loodud globaliseerimisest, mida on kirjeldanud Limor Shifman, Hadar Levy ja Mike Thelwall (Shifman et al. 2014: 728). Kuu lõpupoole, kui teema ka Eesti uudistes järjest aktuaalsemaks muutus, hoogustus 
siingi meemide levik üldiselt ning levis ka rohkem Eesti-spetsiifilisemaid meeme. On võimalik, et neid liikus ka jaanuari kahel esimesel dekaadil, ent siis ehk veidi kitsamas ringis ja seetõttu arhiveerimiseks minuni ei jõudnud, kuid siiski pakun, et nende väiksemat hulka võis põhjustada asjaolu, et teema ei olnud päris viiruspuhangu alguses meil veel eriti aktuaalne, kuna Eestis pole kuigi suurt aasia kogukonda ega otsest transpordiühendust Wuhani ja Hiinaga, polnud kohalikke nakkusjuhtumeid, seega puudus otsene seos viiruspuhanguga.

Joonis 1. Eestlased, nagu ka soomlased ja teised põhjamaade rahvad, võivad kergendunult hingata-sotsiaalne distantseerumine on neile niigi omane (Facebook).

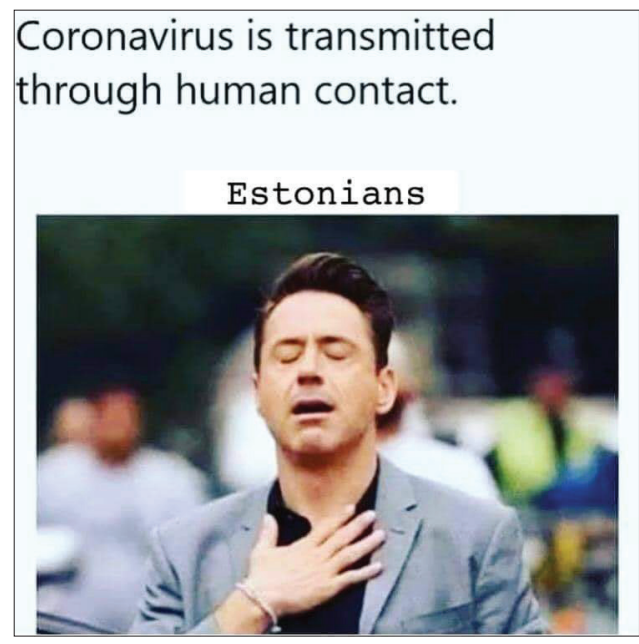

Info ja teadmised viiruse kohta muutusid kiirelt ning uut informatsiooni laekus iga päev, luues omamoodi segu kõige päevakohasemast, sellele vastavaks kohandatud vanematest uudistest ja juba vananenud uudistest, oli ka palju väärinformatsiooni.

Reaalsete uudiste ja valeuudiste või kuulujuttude eristamine on tihtipeale normaalseteski oludes keerukas, sellise kiire uudistetulva juures on aga info vastuvõtjatel veelgi raskem infot analüüsida ja reaalseid lugusid valedest eristada. Lynne S. McNeill on osutanud, et lood ei ringle alati uudisteartiklitena, vaid tihti legendidena (McNeill 2018: 494). Väärinformatsioon ja libauudised võivad esile kerkida erineval moel ning erinevate tagamõtetega või nende seguna, näiteks lihtsa vea või naljana, valeuudised tekivad teadlikult pahatahtliku manipulatsioonina. Haiguspuhangud ei erine muudest märgilise tähtsusega sündmustest, ühiskond reageerib neile tihti kuulujuttude, legendide ja vandenõuteooriatega. Hiliskeskaegsete katkumuistendite ning eelmise sajandi aidsiteemaliste linnajuttude võrdlus näitab, et neil on mitmeid ühisjooni (Hiiemäe 
1999). Ameerika folklorist Jon D. Lee on uurinud eelmise koroonaviiruseepideemia SARSi vastukaja, näidates sarnasusi SARSi ning sellele eelnenud HIV/ AIDSi ja H1N1 gripiga ning leiab, et haigusnarratiivid on pidevas ringluses. Samuti toob ta välja levivate narratiivide tihtipeale kahjustavamagi toime kui haigustel endil oleks (Lee 2014).

Vandenõuteooriate ja -uskumuste üle arutletakse enamasti omamoodi kõlakodades (kindlatel veebilehekülgedel ja -keskkondades, blogides, YouTube’i kanalitel), kus osalevad samalaadse maailmavaate, huvide või uskumustega inimesed. Stabiilses ühiskonnas on neil väiksem osatähtsus, kuid pöördelised sündmused loovad võimaluse uskumustel ja teooriatel kinnisemast keskkonnast avalikumaks tõusta ja enam nähtaval olla ka peavoolumeedias ja sotsiaalmeedias. Sündmuse aktuaalsuse kadudes elavad teooriad (näiteks populaarsed 9/11, vabamüürlased jne) oma elu jälle kitsamas ringis edasi, olles justkui latentses olekus, et olude soodsaks muutumisel taas pinnale kerkida. Otsitakse paaniliselt vaenlast või süüdlast, et mitte uskuda loodusnähtuseid ja loomulikke protsesse, jagatakse "erilisi teadmisi", mida ametlikke uudiseid uskuvad massid ei oma. Erinevad teooriad võivad omavahel põimuda ja üksteist täiendada. Ameerika politoloogi Michael Barkuni klassifikatsiooni järgi võib koroonaviiruse puhul näha nii konkreetse sündmusega seotud kui ka süsteemseid konspiratsiooniteooriaid, peamiselt pakuvad need võimalust uskuda (ning levitada) erinevaid variante viiruse päritolu ja eesmärgi kohta. Viidatakse varasematele, üldse mitte juhtumiga seotud sündmustele, neid tihtipeale omatahtsi teooriale sobivaks muutes. Mõnest vandenõuteooriast võib olla isegi teatud kasu, sest need juhivad ühiskonna tähelepanu probleemidele, kuid enamasti on neid teooriaid seostatud kahjulike tagajärgedega, olgu need siis ühiskondlikud, tervishoiuteemalised või poliitilised (Douglas et al. 2019: 17).

Viiruspuhangu progresseerudes kerkisid esile ka rassimotiivid, uudistes kirjeldasid hiinlaste vältimist mujal maailmas algul hiina päritoluga ajakirjanikud, hiljem mitmete maade Hiinalinnade ettevõtjad. Levivates meemides ja kommentaarides võis seda täheldada viitena aasia toidule (nahkhiiresupp), soovitati vältida köhivaid hiina tudengeid; samuti mõnedes viiruse päritolu teooriates (viirus on laboris tehtud ja/või disainitud nakatama ainult aasialasi/ hiinlasi, teistel rassidel/rahvastel ei ole ohtu) jne. Hiinlaste vältimise vastu jagasid mitmed aasia päritolu inimesed endast pilte sildiga "Mina pole viirus". Siiski võib tõdeda, et puhangu algfaasis ei olnud rassismitemaatika domineeriv ning selle eesmärgiks polnud erinevate rasside vahel pingete õhutamine ja viiruse isoleerimise tõkestamine, erinevalt ebolaviiruse puhangust 2014, mil Nigeeria veebilehtedel levinud vandenõuteooria nn valgete inimeste pettusest väitis näiteks, et viirus on lääneriikides tahtlikult loodud, tihti musta maagia abil, et eurooplastel ja ameeriklastel on uus kultus, mis vihkab aafriklasi 
ning kummardab Ebola-chani - meditsiiniõe kostüümis valget naist, kes hoiab verist kolpa ning kelle pikad juuksed meenutavad ebola viiruse kuju (Kharel 2014). Aafrikas on ebausust tingitud vägivald meditsiinitöötajate vastu niigi suur, neid ründavad inimesed, kes usuvad, et viirust pole olemas või levitavad seda meditsiinitöötajad või et meditsiinitöötajad koguvad neilt organeid Euroopasse müümiseks. Hirm ja vägivald võivad tihti olla ka fataalsed, alles hiljuti tapeti Kongo Demokraatlikus Rahvavabariigis neli ebolaga võidelnud meditsiinitöötajat (Burke 2019). Varasemate viiruspuhangute puhul on käibel olnud ka personifitseeritud viirust või viiruselevitajat kujutavaid meeme, mis võivad olla ka omamoodi kettkirjad, ähvardades haiguse, valu ja surmaga, kui meemi nägija ei postita kästud fraasi postituse kommentaaridesse (nt "I Love You Ebola-chan”, samamoodi ka Zika-chan/Corona-chan/Wuhan-chan).

Leidus ka viiteid Hiina poliitilisele režiimile ja sellest lähtuvatele mõjudele. Inimõiguste rikkumise, tsensuuri, usuliste ja etniliste vähemuste tagakiusamise kriitika oli Hiinast tulevate viiruseuudiste vastukajas olulisel kohal. Hiinas toimuvat kajastada püüdnud kodanikuajakirjanikke kiusati taga ning tihti nad kadusid. Sotsiaalmeedia vastukajades vihjati ka, et viirus on vahend dissidentide ja protestide vaigistamiseks. Jaanuaris ei olnud inimestel Hiinast tuleva informatsiooni ja haigestunute arvudesse suurt usku, eriti pärast seda, kui ilmsiks tuli esialgne varjamine. Kuulujutud viirusest rääkivate arstide, õdede, kodanikuajakirjanike tagakiusamisest levisid ka pärast seda, kui Hiina võimud ei saanud enam eitada situatsiooni tõsidust. Paljudes kommentaarides süüdistati kommunistlikku režiimi andmete ja tegelike nakatunute-surnute arvu võltsimises.

Allpool toon välja mõned peamised teemad ja näited, mida meedia- ja sotsiaalmeediakeskkondadest viiruspuhangu algusfaasis leida võis.

\section{Kahekümnendate aastate needus}

Kuna viirusest saadi esimest korda teada täpselt läänemaailma aastavahetusel ning suurema uudisvoo pealetulekuks oli käes ka Hiina uusaastaperiood, võis jaanuarikuu meemides ja tekstides tihti näha eelmise ja uue aasta võrdlusi, samuti uusaastalubadusi ja teiste jaanuarikuiste tähtsamate sündmuste mainimist. Uusaastalubaduseks oli aastal 2020 ellu jääda; leiti, et 2019. aasta oli küll halb, kuid aasta 2020 on juba esimese kuuga hullem kui 2019; lisaks viirusele olid teemaks ka võimalik kolmas maailmasõda, Austraalia metsatulekahjud ja üleujutused, Kobe Bryanti surm. Samuti leiti, et 2019. aastale peaks järgnema 2019 versioon 2 või tuleks aastat 2020 restartida, sest sel juhul ei saaks neid halbu sündmusi juhtuda. 


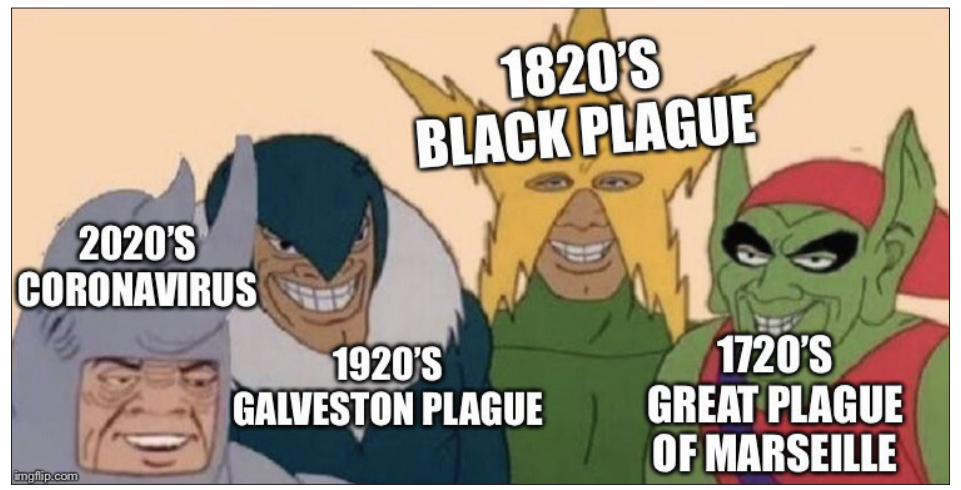

Joonis 2. Internetimeem kujutab suuremaid epideemiaid erinevate sajandite kahekümnendatel aastatel (imgflip.com).

Nii meemides kui ka kommentaarides toodi välja ka eelmisi haiguspuhanguid, mis on juhtunud erinevate sajandite kahekümnendatel aastatel, igal sajandil olevat olnud just neil aastail suur pandeemia (1720 - Marseille' katk, 1820 koolera pandeemia, 1920 - Hispaania gripp), mis järgib sama mustrit nagu tänavune puhang Hiinas. Vihjati ka, et see ei saa olla juhus, kindlasti olevat mängus mingi kuri käsi, seega võib märgata läbipõimumist vandenõuteooriatega. Haiguspuhanguid on olnud muidugi palju rohkem ja ka muudel aastakümnenditel, kuid välja on nopitud parasjagu situatsiooniga sobiv. Erinevalt teistest põhilistest tüüpidest, mis on käibel ka edaspidi, jäi selle rühma aktuaalsus peamiselt aasta algusesse.

\section{Meelelahutusmaailm koroonakajas}

Palju on viiteid meelelahutusmaailmale, olgu selleks siis mängud või filmid ja telesaated, teema on neis väga levinud, eriti apokalüptilistes mängudes ja filmides. Tüüpiliste meemipõhjadena on kasutusel palju filmide, telesarjade, multikate tegelasi. See tendents on levinud ka muudes oludes. Oma koha on koroonaviiruse vastukajades leidnud ka mitmed kunstiteemalised meemid, näiteks "Püha õhtusöömaaeg" ilma einestajateta, all kiri "Cancelled" või "Venuse sünd" näomaski, kummikinnaste ja kilesussidega.

Arvutimängudest domineerib koroonakajades Plague Inc., kuid mainitakse ka nt World of Warcrafti jt. Plague Inc. on reaalajas toimuv strateegiamäng, kus mängija loob ja arendab patogeeni, püüdes inimkonda surmava katkuga hävitada. Mäng kasutab realistlike muutujatega epidemioloogilist mudelit tõve 
leviku ja raskuse simuleerimiseks. Tõdeti, et mäng on saanud tõelisuseks, on vaja leida, KES seda mängib või vihjatakse, et Jumal on mängija:

When God decided to play Plague inc. [Kui Jumal otsustas mängida mängu Plague Inc.] (EFITA F32-001-0017)

Plague inc has come to real life. We need to find out who is playing it [Plague Inc. on jõudnud pärisellu. Me peame välja uurima, kes seda mängib.] (EFITA F32-001-0021)

Levinud olid soovitused kolida Gröönimaale, kuna mängus on see kõige raskem maa, mida nakatada.

Vastukajades kerkisid esile paljud epidemioloogilise sisuga filmid, kust otsiti paralleele praeguse haiguspuhanguga, näiteks ameerika thriller "Nakkus" (Contagion, 2011), telesari "Pandeemia" (Pandemic, 2007), Lõuna-Korea filmid "Gripp" (The Flu, 2013) ja "Rong Busanisse" (Train to Busan, 2016). Näiteks soovitati filmile “Train to Busan" järge pealkirjaga "Planes from Wuhan”. Jaanuari lõpupoole hakkas Netflix näitama verivärsket dokumentaalsarja "Pandemic: How to prevent an outbreak", mille ajastus tekitas samuti palju ärevust.

Uudistesse jõudis ka Simpsonite sari koronaviiruse ettekuulutajana (sarjas küll Osaka gripp Jaapanist). Simpsoneid on ka varem esile tõstetud täpsete ennustuste tõttu, tuntuimad ettekuulutuse näited on Donald Trumpi saamine USA presidendiks, Higgsi bosoni avastamine, automaatkorrektuuri loomine, nutikellad jne. 1. veebruaril Eestissegi jõudnud uudise peale leidis üks siinne kommentaator:

Ei vasta tõele, Koroonaviirust ennustas Eesti kultusdraama "Tõde ja õigus”, kogu universumi ainuke vä̈̈rtfilm (EFITA F32-002-0006).

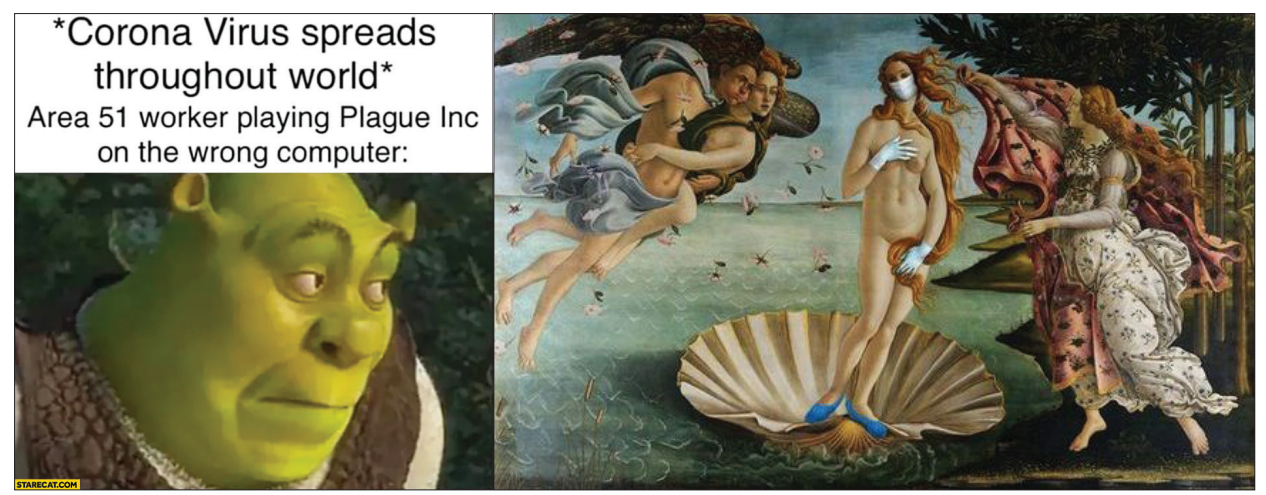

Joonis 3. Meeme meelelahutusmaailma ja kunsti teemadel (starecat.com, Facebook). 


\section{Nahkhiiresupp, Made in China, Kung Flu - hiinateemalised reaktsioonid}

Viirusest teadasaamisest peale hakati spekuleerima selle päritolu üle. Ametlike andmete kohaselt on viiruse leviku alguskohaks turg, mis kauples muuhulgas ka illegaalsete elusloomadega, see oli paljude hiina köögi ja toitumistavadega seotud reaktsioonide ajendiks. Näiteks levis viraalne video hiinlannast, kes väidetavalt sõi Wuhanis nahkhiiresuppi, mis tekitas pahameeletormi sotsiaalmeedias, viiruse vallapuhkemises süüdistati hiinlaste toitumistavasid. Video oli tegelikult filmitud 2016. aastal Vaikse Ookeani arhipelaagis ning sellel polnud Wuhani turu või viirusega mingit pistmist, kuid sotsiaalmeedias kõlbab võimsaks katalüsaatoriks iga asi.

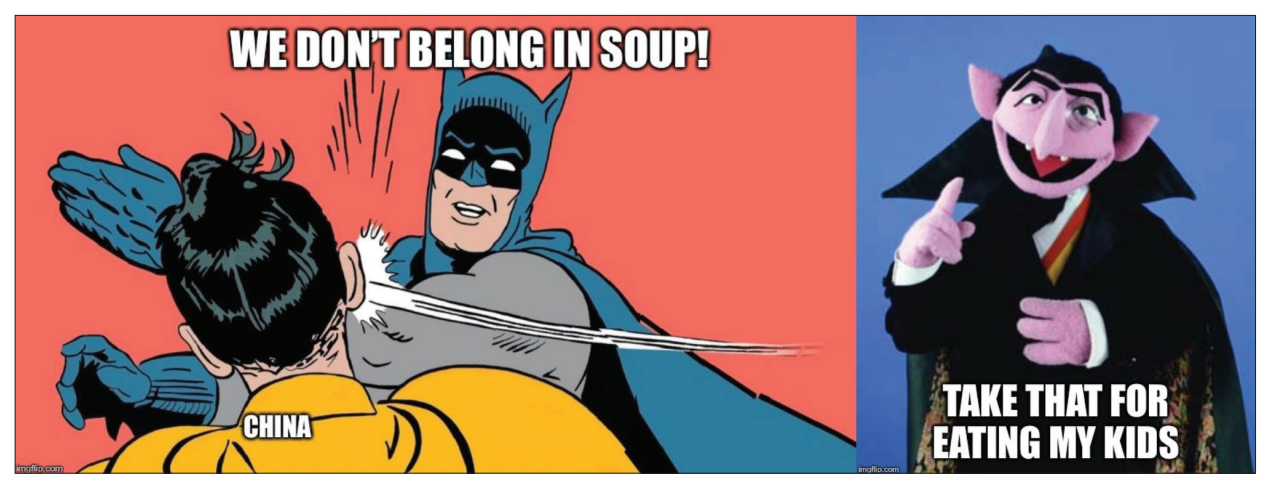

Joonis 4. Hiina toitumistavade ja nahkhiireteemalised meemid (imgflip.com).

Leiti ka, et ülejäänud maailmal pole mõtet muretseda - viirus ei kesta kaua, see on ju tehtud Hiinas. Vahel tõdeti küll seepeale, et peaaegu kõik meie globaliseerunud maailmas on pärit Hiinast.

Viiruse levimise kiirus ja mehhanismid tundusid puhangu algul olevat sarnased gripile, mis omakorda tõi kaasa Kung Flu meemid (Kung Flu on Urban Dictionary järgi algselt Aasiast pärit grippide kohta käiv släng, mida kasutatakse ka uue koroonaviiruse kohta), sõnapaari kasutatakse nii viiruse enda märkimiseks kui ka viirusega võitlemiseks kasutatava võitluskunsti tähenduses, nt meem rahustava olekuga arstist kinnitamas, et pole vaja muretseda, ma oskan Kung Flud. Viirust on nimetatud ka Wuhani gripiks või lühendatuna WuFluks. 


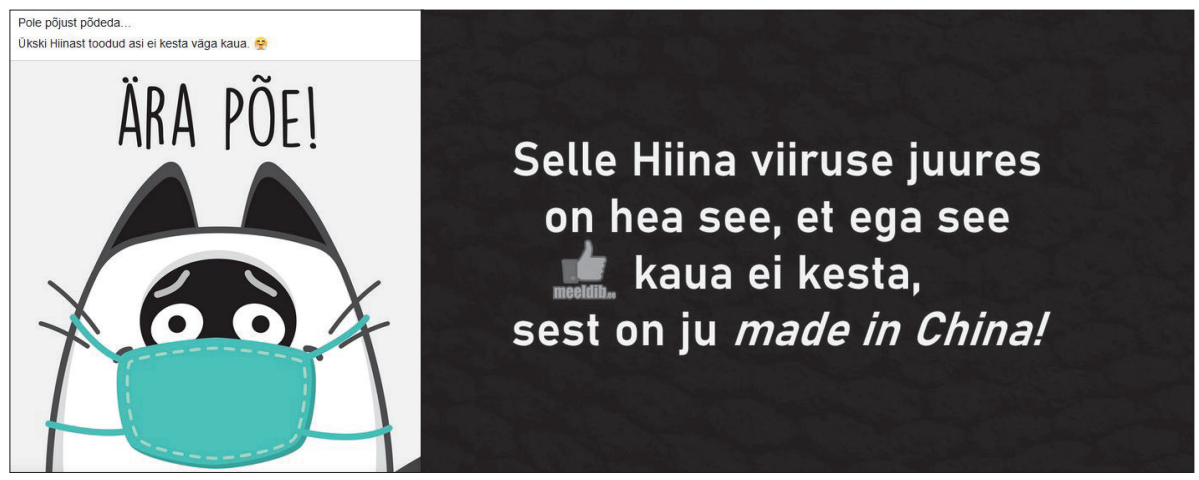

Joonis 5. Kuna viirus on tehtud Hiinas, siis pole vaja muretseda - see ei kesta kaua (Facebook, meeldib.ee).

\section{Koroonaviiruse nimega seotud meemid}

Koroonaviiruse nimi on andnud hea võimaluse seostada seda Mehhiko Corona õllega. Teemad varieeruvad: Corona õlu võib olla nii viiruse levitaja kui ka ravi või vaktsiin või põhjendus mitte tööle minna, leidus libauudiseid, et õlletootja kaebab Hiina valitsuse kohtusse, sest nimi jätab nüüd inimestele halva maitse suhu, või muudab õlle nime Coronast Ebolaks; kuna õlut juuakse laimiviiluga, levinud on viited ka puukborrelioosile (Lyme’i tõbi), soovitused, et ravi koroonaviiruse vastu võib olla teine õllemark jne. Meemipõhjadena on kasutatud peamiselt õllereklaame mitmete viirusega seotud tekstiliste vihjetega.

On täheldatud, et Google viiruste/haigusteteemalised otsingud on puhangute ajal tipus, nii on kirjeldatud 2014. aastal ebolaviiruse puhangu ning nüüd ka uue koroonaviiruse puhul. Seekord on aga välja toodud, et viiruseuudiste tihenedes sagenesid märkimisväärselt otsingud corona beer virus, beer virus ja beer coronavirus. Ajavahemikus 18.-26. jaanuarini tõusis corona beer virus päringute arv $2300 \%$ (Bostock 2020).

Joonis 6. Viiruse nime tõttu kasutati paljudes meemides ja libauudistes Corona õlle teemat (imgflip.com, starecat. com).

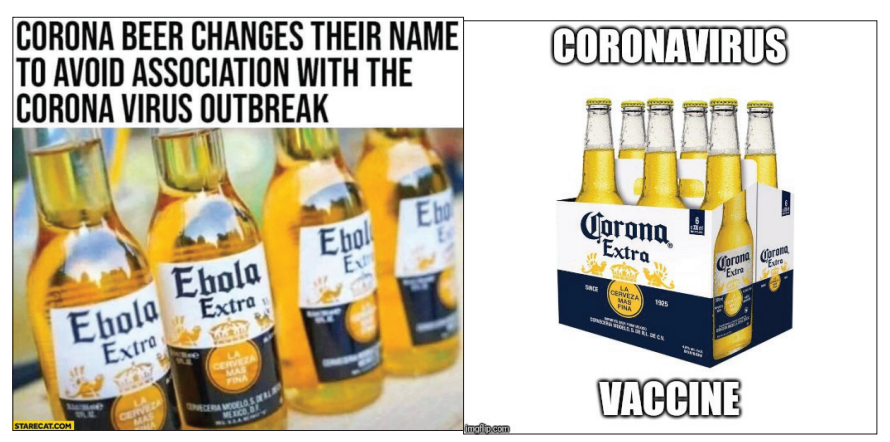


Eesti-spetsiifilisema näitena kuuluvad siia ka viited koroonamängule.

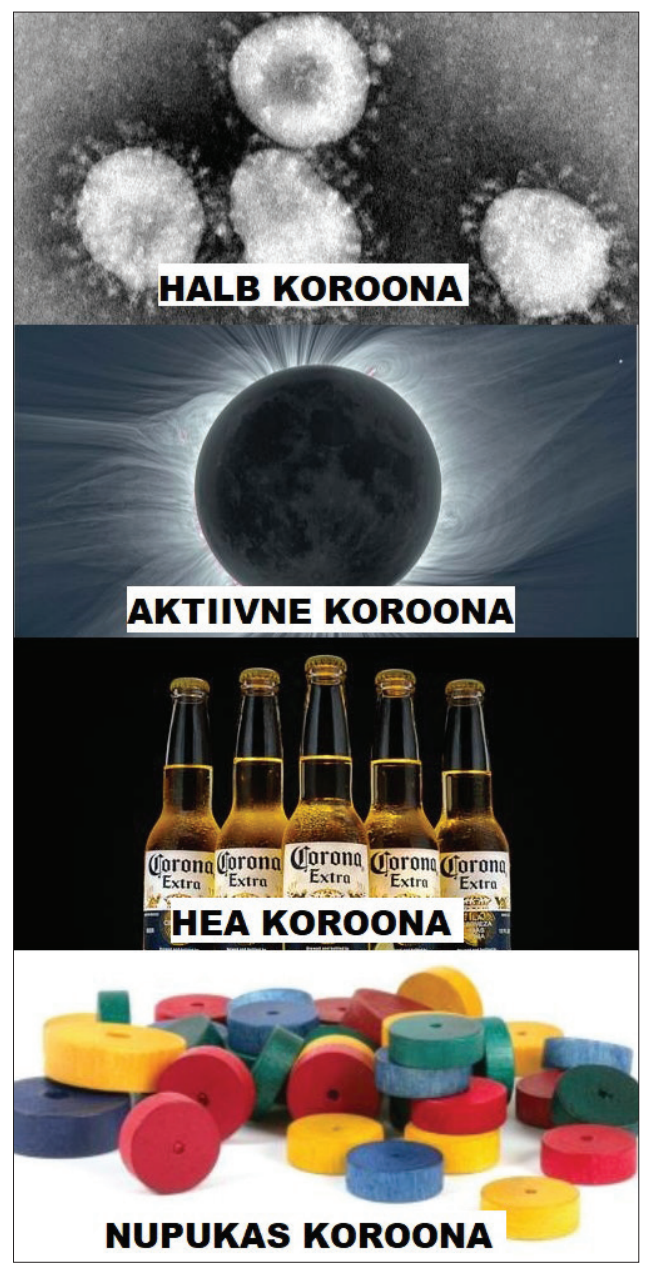

Joonis 7. Koroonateemaline meem eesti finantsfoorumist (lhv.ee).

\section{Karikatuurid}

Viiruseteema jõudis lisaks uudistele ka väljaannete karikatuuridesse, mis avaldamisel omakorda võisid vallandada tagasiside. Ehk kõige skandaalsem oli Taani ajalehe Jyllands-Posteni karikatuur 27. jaanuarist 2020: karikaturist Niels Bo Bojesen kujutas Hiina lippu, millel tähtede asemel on kujutatud 
koroonaviirust. Sama ajaleht avaldas ka skandaalsed Muhamedi-karikatuurid 2005. aastal, põhjustades rahvusvahelise skandaali, mis viis protestide ja vägivallani 2006. aasta alguses. Toona põletati Taani lippe, rünnati Taani ja Euroopa diplomaate, kirikuid ja kristlasi, vägivallalaines sai surma üle 250 inimese (Muhammad cartoons controversy). Õnneks seekord nii tõsiseid reaktsioone ei tekkinud, kuid Hiina saatkond nägi karikatuuris Hiina ja hiinlaste solvamist ning nõudis ajalehelt ja karikaturistilt avalikku vabandust. Ajalehe peatoimetaja Jacob Nybroe vastas, et karikatuuri eesmärk ei olnud Hiina üle nalja teha, eriti olukorras kus juba rohkem kui sada inimest oli uude viirusesse surnud ning nad ei kavatse vabandada millegi eest, mis ei ole vale. Ta tõi esile Taanile iseloomulikku sõnavabadust, mis kehtib ka karikatuuride puhul ja millele ajaleht kindlaks jääb ning viitas, et tegemist on kultuurierinevustega (The Local 2020).

Karikatuurile sai selline esiletõstmine kahtlemata reklaamitrikiks, uudis levis ka mujal maailmas ning hakkas levima meemina sotsiaalmeedias, millele järgnes muidugi kopeerimine, muutmine, vastusena ka Taani lippude muutmine.

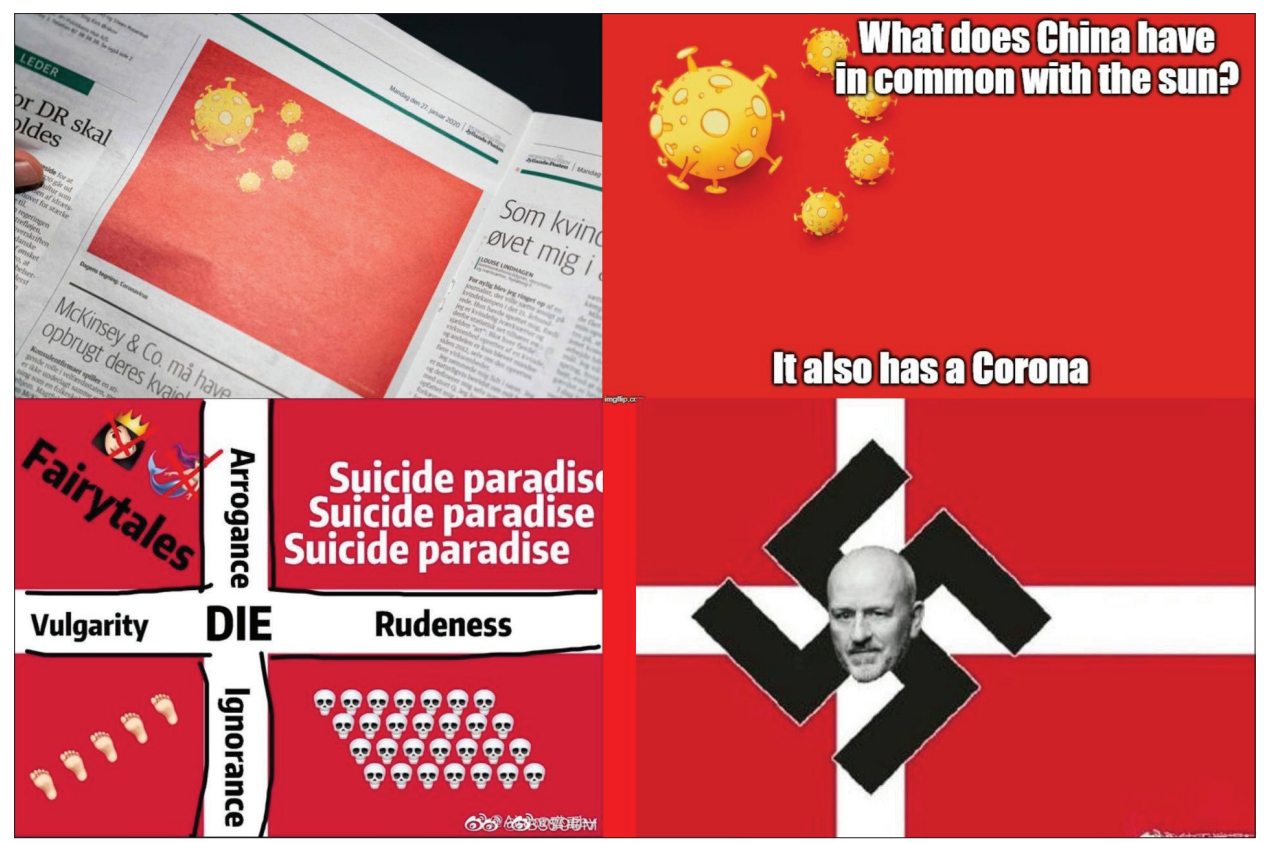

Joonis 8. Originaalillustratsioon Jyllands-Postenist ja vastused sellele imgflip.com, Twitter and Weibo keskkondadest. 


\section{Teooriad viiruse päritolu ja leviku kohta}

Ehk kõige suuremaks paisunud kommentaaride-meemide rühm on kõikvõimalikud vandenõuteooriad viiruse päritolu ja eesmärgi kohta. Äkiline ja kiire haiguspuhang, nagu iga teinegi pöördelise tähtsusega sündmus, pakkus suurepärase võimaluse kiirelt muutuvaid uudiseid mitmel moel tõlgendada ja pakkuda erinevaid variante. Jaanuari algupoolel oli tavameedia selles osas veel suhteliselt vaikne, aga pärast 20. jaanuari, mil infohulk oluliselt suurenes ja uudised Hiinast igapäevaseks muutusid, hakkasid ka need rohkem nähtavaks saama. Seati kahtluse alla Hiina algne ametlik kinnitus, et viirus on seotud mereandide turuga ning kuu lõpuks oli arenenud mitmeid teooriaid, mõned neist lükati kohe ümber ja kadusid peagi, teised ringlevad senini.

Üks esimesi oli teooria, et Hiina agendid või teadlased varastasid viiruse Kanadast ja smugeldasid Hiinasse, kus see arendati biorelvaks. Kanada lükkas peagi selle võimaluse ümber. Seejärel on viiruse vallapäästmises süüdistatud teisi riike (peamiselt USAd, eriti seoses kaubandussõjaga, aga ka Inglismaad, Saksamaad või Venemaad). Eriti laialdaselt levis artiklites ja videotes arvamus, et viirus on lahti pääsenud Wuhani P4/BSL-4 biolaborist, kus tegeldakse eriti ohtlike patogeenidega, millel on kõrge suremus ja pole spetsiifilist ravi (ebola, SARS jne). Pakuti, et Hiina sõjavägi arendab seal biorelvi ja uus koroonaviirus ongi üks neist:

It came from a bioweapons lab. It didn't jump from animals to humans. [See on pärit biorelvade laborist. See ei hüpanud loomadelt inimestele.] (EFITA F32-001-0167)

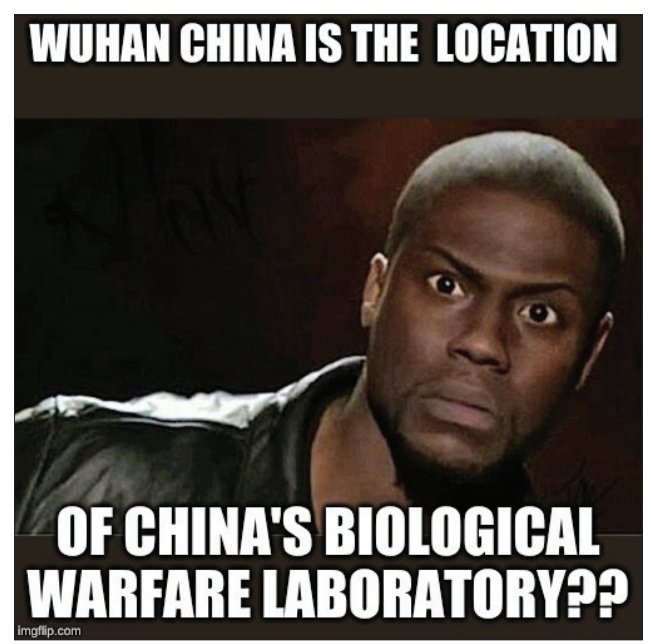

Joonis 9. Hiina biorelva teemaline meem (imgflip.com). 
Laborist lahtipääsemise teooriat toetasid varasemad ajaleheartiklid, kus USA bioohutuse eksperdid väljendasid muret, et viirused võivad ettearvamatute laboriloomade tõttu välja pääseda. Levis ka pilt väidetavast Wuhani biolabori logost, mis on kahtlaselt sarnane Umbrella Corporationi logoga "Resident Evil" mängudest/filmidest, firma oli vastutav viiruse lahtipääsemise eest. Tuli aga välja, et tegemist on hoopis Shanghais asuva labori logoga, mil pole Wuhaniga midagi pistmist.

Levisid ka tavapärased jutud ravimifirmade kohta, neid süüdistati viiruse levitamises eesmärgiga esmalt paanikat külvata, et seejärel vaktsiine ja ravimeid müües suurt kasu teenida. Paljudel juhtudel arvati, et vaktsiin või ravi on juba enne viiruse lahtilaskmist välja töötatud:

Corona virus is a patented disease which means there's also a patented cure. Look it up. [Koroonaviirus on patenteeritud haigus, mis tähendab, et sellele on ka patenteeritud ravi. Vaata järele.] (EFITA F32-001-0062)

See teooria on ringluses olnud ka varasematel juhtudel ja erinevate haiguste kohta. Samuti seatakse kahtluse alla viiruse zoonootiline olemus, viiruste võime muteeruda, vahel ka üleüldse tänapäevane teaduslik maailmapilt. Leitakse, et viiruse loomadelt inimestele levimise põhjendus ei saa olla õige - nii on ju elatud või toitutud juba sajandeid, miks seda siis varem juhtunud pole? Nii jõuame jälle tagasi laboris tehtud viiruseni.

Veel üks levinud vandenõuteema on Event 201, kõrgetasemeline rahvusvaheline pandeemiasimulatsioon, mis toimus üsna enne viiruspuhangu algust, 18. oktoobril 2019. Õppuse korraldasid Johns Hopkinsi Terviseohutuse Keskus koostöös Maailma Majandusfoorumi ning Bill ja Melinda Gates’i fondiga. Simulatsiooni eesmärk oli osutada valdkondadele, kus avalik ja erasektor peaksid pandeemia korral koostööd tegema, et vähendada tõsiseid majanduslikke ja ühiskondlikke tagajärgi (Event 201). Stsenaarium nägi ette uue koroonaviiruse pandeemiat, mille tõttu esimese 18 kuu jooksul sureb 65 miljonit inimest. Hoomamata ilmselt tõelise pandeemiaga kaasnevat mõju kogu ühiskonnale pandi pahaks, et harjutuse eesmärgiks polnud tervis ja inimeste heaolu, vaid valitsustele ja suurkorporatsioonidele olulised majanduslikud tagajärjed. Kuna reaalne viirusepuhang (koroonaviirus) juhtus kohe pärast simulatsiooni, siis arvatai, et see ei saa olla kokkusattumus või vihjati, et see oli ettekuulutus. Epidemioloogilise sisuga simulatsioone tehakse siiski eri tasanditel järjepidevalt, lisaks teaduslikule ja poliitilisele aspektile võivad need tugineda ühiskonna mälule, ajaloolistele uurimustele ja süstemaatilisele terviseandmete töötlemisele (Keck \& Lachenal 2019: 28). Harvem on mainitud ka teise miljardäri George Sorosega seotud samalaadset simulatsiooni Food Chain Reaction: A Global Food 
Security Game ${ }^{2}$ (2015), mille stsenaariumi järgi viis aastat hiljem on rahvastiku juurdekasvu, kiire linnastumise, ekstreemsete ilmaolude ja poliitiliste kriiside kombineerumise tõttu (ning kommentaatorid rõhutavad: haigus! 2020!) tõsine oht maailma toiduga varustatusele. Küsitakse, kas need simulatsioonide stsenaariumid saavad nüüd reaalsuseks ning kelle süül ja huvides.

Bill Gates on kas siis üksikisikuna või Bill ja Melinda Gates’i Fondi esindajana ühiskonda juba aastaid hoiatanud, et suurim globaalse katastroofi oht oleks uus väga nakkav viirus, ning osundanud, et pole efektiivseid plaane või strateegiaid pandeemia peatamiseks või sellega võitlemiseks. Teda seostatakse ka depopulatsiooniteemalise konspiratsiooniteooriaga, mille kohaselt on viirus disainitud ja tahtlikult levitatud rahvastiku kontrollimiseks. Samuti on vihjatud, et just temal on patent viirusele ja olemas ka vaktsiin.

Nii jõuame sajandeid vana kontseptsioonini, et eliit, olgu selleks aegade jooksul olnud aristokraadid, mõisnikud või miljardärid, on süüdi haiguste levitamises ja muudes inimkonda tabanud hädades. Eesti Rahvaluule Arhiivi materjalidest võib leida teateid mõisnike levitatud katku, koolera ja loomataudi kohta (Hiiemäe 1997: 111-114), Eesti Kultuuriloolise Arhiivi ajaloolise pärimuse kogus on samuti teade mõisniku teenistuses olevate kurjade inimeste kohta, kes koolerat levitasid, teisalt ka, et mõisnik teadis toimivat ravi ning küla pääses tõvest (Tavast 2020 [1931]).

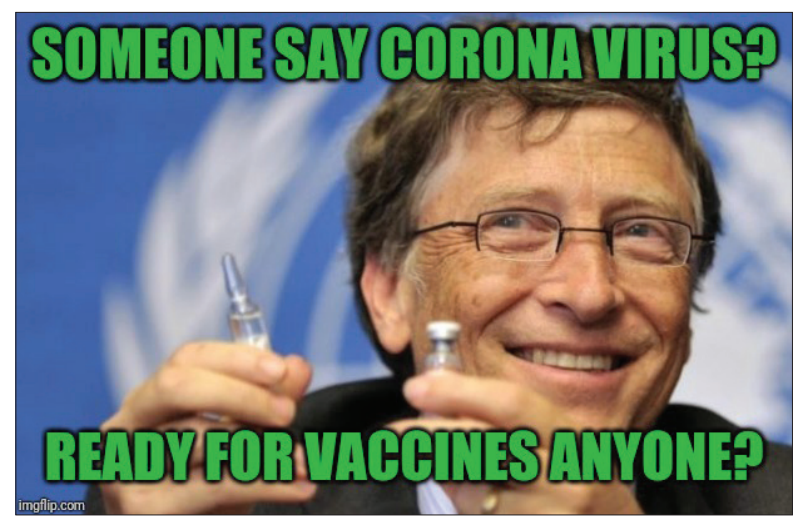

Joonis 10. Kas keegi sooviks vaktsiini? (imgflip.com). 


\section{SARS-CoV-2 ja teised viirused}

Viiruspuhangu algfaasis hindasid meedikud, et uus koroonaviirus on tunduvalt vähem surmav kui seni teadaolevad tõsised koroonaviirused SARS-CoV ja MERS-CoV, kuid võib olla sama nakkav kui sesoonne gripp. Vastukajana viitasid paljud iga-aastastele surmadele sesoonse gripi, kasvajate või südameveresoonkonnahaiguste tõttu, näidates, et praegune viirus ei ole tõsine, vaid meedia poolt õhutatud paanika nagu varasemadki kaasaegse meediaajastu epideemiad. Tihti kohtab arrogantseid vastuseid stiilis: tavaline külmetus, ärge muretsege, surevad vaid vanad ja nõrgad. Kuna tegemist on täiesti uue viirusega, mille vastu pole inimestel antikehi, pole ei vaktsiini ega kindlakstehtud toimivat ravi, polnud meditsiinisüsteemi ülekoormatuse tõttu piisavalt võimalusi ravida kiirelt kasvavat raskes ja kriitilises seisus patsientide hulka, oli olukord Wuhanis jaanuari lõpuks tõepoolest väga tõsine. Sel hetkel oli veel liiga vara hinnata viiruse reproduktsiooni alusarvu $\left(R_{0}\right.$ ehk nakkusliku isendi poolt tekitatud sekundaarsete nakkuste keskmine arv naiivses populatsioonis), kergete ja raskete või kriitiliste intensiivravi vajavate juhtude jaotust ja letaalsust (CFR, haigusesse surnute proportsioon haigestunute koguhulgas teatud perioodi jooksul).

Eituse faas levis ka Eesti sotsiaalmeedias ja kommentaariumides:

Idiootidele mõeldud paanika,mingit koroonat ei ole olemas. Meditsiin võib rahus neid maske sööma hakata-teid ei usuta,tolvanikari! (EFITA F32-002-0005)

\section{Reageerimine riiklikele meetmetele}

Viiruse levides hakkasid naaberriigid sulgema oma piire Hiinaga ning arutluse alla tulid võimalikud rahvusvahelised reisipiirangud. Pärast Wuhani ja naaberlinnade sulgemist 23. ja 24. jaanuaril plaanisid teised riigid hakata oma kodanikke epitsentrist evakueerima. See tekitas pahameelt nii kohalike hulgas, kes kartsid viiruse maaletoomist, kui ka potentsiaalsete evakueeritavate seas - me ei soovi ju teisi nakatada. Hakkas tekkima pahameel nii oma maade valitsuste kui Maailma Terviseorganisatsiooni vastu, leiti, et ette võetud meetmed ei ole piisavad haiguspuhangu leviku ohjeldamiseks. WHO rõhutas, et pole mingit põhjust piirata reisimist ja kaubandust, sest see oleks kahjulik majandusele ja seega kogu maailmale. Enamik suuremaid lennukompaniisid lõpetas siiski jaanuari lõpuks lennud mandri-Hiinasse. WHO kiitis järjepidevalt 
Hiina meetmeid viiruse leviku vastu ning Hiinast laekuva info läbipaistvust, seetõttu süüdistati WHOd Hiina kompartei käpa all olemises.

Kuna viirusest, selle levimisviisist, inkubatsiooniperioodist ei olnud veel kuigi palju teada, kasutasid riigid Hiinast tagasipöördujatega käitumisel ka väga erinevaid strateegiaid. Mõned ei pidanud karantiini vajalikuks, sest eeldati, et viirus levib vaid sümptomite ilmnedes ja piisab peamiste sümptomite (palavik, köha) kontrollist lennujaamades, seegi tekitas ühelt poolt süüdistusi, et valitsused reageerivad probleemile liiga uimaselt, teisalt neile vastuseks väiteid, et tegemist on täiesti kahjutu viirusega, see on ainult pettus või meedia poolt üles köetud paanika. Teised riigid olid ettevaatlikumad ning hakkasid mõtlema ka karantiini vajalikkusele. Info viiruse kohta täienes sel perioodil lausa tundidega, seetõttu vaadati pidevalt üle ka plaanitavaid meetmeid.

Esimestena evakueerisid oma kodanikud Wuhanist USA ja Jaapan (esimesed lennud 28. ja 29. jaanuaril). Ka Ühendkuningriik ja Saksamaa teatasid evakuatsiooniplaanidest ning kinnitasid, et naasvad kodanikud peavad pärast saabumist läbima karantiini. See toob esile uue aspekti - vastusena Briti terviseministri Matt Hancocki twitterisäutsule kerkis lisaks ühiskonna ja rahvatervise turvalisusele esile inimõiguste teema seoses tagasitulijate karantiiniga (The Guardian 2020).

Kohalikule kogukonnale tuli tihtipeale üllatusena, et valitsused on otsustanud evakueeritud nende lähikonda paigutada - näiteks Austraalias (Jõulusaar) ja Kanadas. Austraalia evakueeritud viidi Jõulusaarele, piirkonna president Gordon Thompson ei olnud rahul, et seda polnud kohalikega läbi arutatud. Oma vastureaktsioonis viitas ta ka stigmatiseeritud leeprale (Michelmore \& Parish \& O’Connor 2020). Kohalike hirm, et viirus sel viisil lähikonda tuuakse, on ilmne.

Sakslased evakueeriti Wuhanist Luftwaffe lennukiga ning viidi karantiini sõjaväeosasse Germersheimis, mis andis alust Teise maailmasõja ja koonduslaagriteemalistele võrdlustele:

'Germany' and 'camp' in one sentence. Risqué haha! ['Saksamaa' ja 'laager' ühes lauses. Riskantne haha!] (EFITA F32-001-0096)

coronacaust? (EFITA F32-001-0109)

Auschwitz'20 (EFITA F32-001-0110)

Teisedki riigid evakueerisid jaanuaris-veebruaris oma kodanikke, kuid evakueeritute arv on marginaalne võrreldes reisijatega, kes omal käel Hiinast ja Wuhanist lahkusid. Enne Wuhani linna sulgemist jõudis teate peale linnast lahkuda hinnanguliselt viis miljonit inimest, pärast sulgemist oli veebruari keskpaigaks telefonikompaniide andmetel sealt lahkunud lisaks 150000 abonenti. 
Uudistekanalid hakkasid avaldama intervjuusid evakueeritutega ja karantiinis olijatega, tekkisid kiirelt populaarseks muutuvad videoblogid, kus inimesed jagasid oma igapäevamuljeid ja kogemusi. Sel moel jõudsid konkreetsed inimesed lugejatele-vaatajatele lähemale, said tuttavaks ning üldiselt muutus ka vastukaja positiivseks ja heasoovlikuks.

\section{Kokkuvõtteks}

Info esimestest teadmata etioloogiaga kopsupõletikest Hiinas Hubei provintsi Wuhani linnas jõudis Maailma Terviseorganisatsiooni 31. detsembril 2019. Peagi sai selgeks, et tegemist on uut tüüpi koroonaviirusega, mis hakkas kiirelt levima. Kohalikud võimud püüdsid algul infot uuest võimalikust viirusest varjata, vaigistades sellest rääkinud meedikud ning süüdistades neid sotsiaalse korra rikkumises. Usutakse, et info varjamine võis aidata kaasa puhangu kiiremale eskaleerumisele.

Kui Hiinast hakkas saabuma regulaarselt ametlikult kinnitatud andmeid, suurenes olukorra kiire eskaleerumise tõttu märkimisväärselt viiruseinfo hulk lääne meedias. Nagu iga teisegi olulise sündmuse puhul, saab jälgida justkui plahvatust sotsiaalmeedias: alates igal moel avaldatud, jagatud, muudetud ja kommenteeritud uudistest, lugudest ja lauludest, situatsiooni klikipüüdjaks kasutavatest sotsiaalmeedia sisuloojatest kuni arvutiviiruste levitamiseni (Paganini 2020) - kõik püüavad inimeste kasvavat huvi enda kasuks pöörata. Näeme nalju, meeme, nii pahatahtlikke valeuudiseid kui ka inimlikust veast või teadmatusest levivat väärinformatsiooni, vandenõuteooriaid ja sotsiaalmeediaplatvormide püüdeid neid vaos hoida. Mõned platvormid kasutasid faktikontrollijaid, et valeinfot ja paanikaõhutamist piirata (Facebook, Instagram),

WHO WOULD WIN?

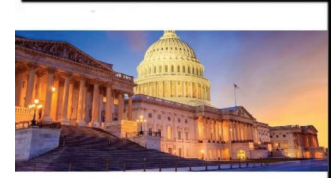

an entire government

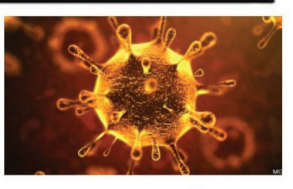

one evil little tiny boi

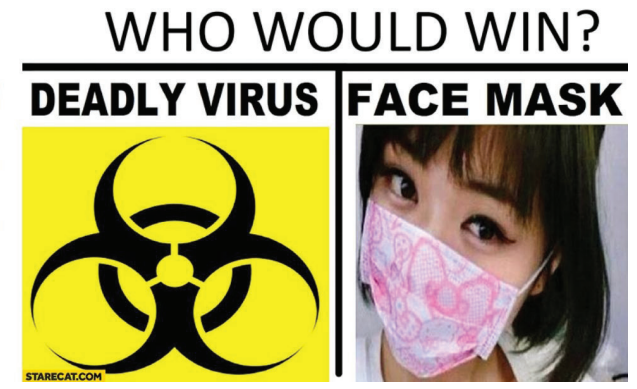

Joonis 11. Meemides mõtiskletakse ka viiruspuhangu tuleviku üle.

Vastus küsimusele selgub alles hiljem (imgflip.com, starecat.com). 
mõni kasutas reklaamikeeldu või kõrvaldas viiruseteemalised videod, et huvi nende tootmise ja levimise vastu vähendada. Kuulujuttude ja valeinformatsiooni hulk oli puhangu algusfaasis nii suur, et veebruaris avaldasid üheksa riigi rahvatervise teadlased meditsiiniajakirjas Lancet ühispöördumise, milles mõistsid teravalt hukka levivad teooriad viiruse tehisliku päritolu kohta, kinnitades, et mitmete riikide teadlased on analüüsinud põhjustaja genoome ning järeldanud, et see on pärit loodusest (Calisher et al. 2020).

Viiruspuhangu kiire eskaleerumine võimaldas jälgida, kuidas esimese kuu teemakohaste uudiste fookus ja vastavalt ka rahva tagasiside muutus lausa päevade jooksul millestki võõrast ja kaugest lähedaseks ning nii meditsiinilises kui ka majanduslikus mõttes kogu maailma puudutavaks. Tänapäeval seninägematud karantiinid ja linnade sulgemised maailma suurimas tööstusriigis lõikasid läbi globaliseerunud maailmale nii olulised tarneahelad peaaegu igas valdkonnas. Hiina võimude rakendatud drakooniliste meetmetega saadi viirus loodetavasti kohapeal kontrolli alla ning suudeti viiruse massilist levikut teistesse riikidesse pidurdada, et anda vähemalt teoreetiline võimalus paari võidetud lisanädala jooksul teiste riikide tervishoiusüsteeme suureks raskete ja kriitilises seisus haigete hulgaks paremini ette valmistada. Koroonaviiruse mõjud saavad järjest tuntavamaks igas eluvaldkonnas, majandusest ja aktsiaturgude langusest tervete linnade ja riikide sulgemisteni. Lõplikke mõjusid ülemaailmsele rahvatervisele ja majandusele on paraku võimalik hinnata alles pärast pandeemia lõppu.

\section{Tänuavaldus}

Artiklit on toetanud projekt EKM 8-2/20/3 ja EU regionaalarengu fond Eestiuuringute Tippkeskuse (CEES - TK 145) vahendusel.

\section{Kommentaarid}

1 https://knowyourmeme.com/ - 21. veebruar 2020.

${ }^{2}$ https://foodchainreaction.org/ - 30. märts 2020. 


\section{Allikad}

Muhammad cartoons conroversy $=$ Jyllands-Posten . Muhammad cartoons controversy . Wikipedia (https://en.wikipedia.org/wiki/Jyllands-Posten_Muhammad_cartoons_ controversy - 30. märts 2020).

Wenliang $=$ Li Wenliang. Wikipedia . The Free Encyclopedia (https://en.wikipedia.org/ wiki/Li_Wenliang - 30. märts 2020).

WHO 2020a = Pneumonia of unknown cause - China. Emergencies preparedness, response. World Health Organization (kodulehekülg) 05.01.2020 (https://www.who. $\mathrm{int/csr/don/05-january-2020-pneumonia-of-unkown-cause-china/en/} \mathrm{-} \mathrm{30.} \mathrm{märts} \mathrm{2020).}$

WHO 2020b = Novel. Coronavirus - China. Emergencies preparedness, response. World Health Organization (kodulehekülg) 12.01.2020 (https://www.who.int/csr/don/12january-2020-novel-coronavirus-china/en/ - 30. märts 2020).

WHO 2020c $=$ Coronavirus disease (COVID-19) Pandemic. World Health Organization (https://www.who.int/emergencies/diseases/novel-coronavirus-2019 - 30. märts 2020).

WHO $2020 \mathrm{~d}=$ Novel. Coronavirus $(2019 \mathrm{nCoV})$. Situation Report 11. World Health Organization (https://www.who.int/docs/default-source/coronaviruse/situationreports/20200131-sitrep-11-ncov.pdf?sfvrsn=de7c0f7_4 - 30. märts 2020).

\section{Kirjandus}

Blank, Trevor (toim) 2009. Folklore and the Internet. Vernacular Expression in a Digital World. All USU Press Publications. Book 35. Utah State University Press.

Bostock, Bill 2020. People seem to think Corona beer is related to the deadly Wuhan coronavirus outbreak, as searches for 'Corona beer virus' are trending. Business Insider, 29. jaanuar (https://www.businessinsider.com/coronavirus-corona-beer-not-relatedgoogle-trends-2020-1 - 30. märts 2020).

Burke, Jason 2019. Ebola health workers killed and injured by rebel attack in Congo. The Guardian, 28. november (https://www.theguardian.com/global-development/2019/nov/28/ ebola-health-workers-killed-and-injured-by-rebel-attack-in-congo - 30. märts 2020).

Calisher et al. 2020 = Calisher, Charles \& Carroll, Dennis \& Colwell, Rita \& Corley, Ronald B. \& Daszak, Peter \& Drosten, Christian \& Enjuanes, Luis \& Farrar, Jeremy \& Field, Hume \& Golding, Josie \& Gorbalenya, Alexander \& Haagmansm Bart \& Hughes, james M. \& Karesh, William B. \& Keusch, Gerald T. \& Lam, Sai Kit \& Lubroth, Juan \& Mackenzie, John S. \& Madoff, Larry \& Mazet, Jonna \& Palese, Peter \& Perlman, Stanley \& Poon, Leo \& Roizman, Bernard \& Saif, Linda \& Subbarao, Kanta \& Turner, Mike. Statement in support of the scientists, public health professionals, and medical professionals of China combatting COVID-19. The Lancet, 19. veebruar (doi: 10.1016/ S0140-6736(20)30418-9). 
Denisova, Anastasia 2019. Internet Memes and Society. Social, Cultural, and Political Contexts. New York \& Oxon: Routledge.

Douglas, Karen M. \& Uscinski, Joseph E. \& Sutton, Robbie M. \& Cichocka, Aleksandra \& Nefes, Turkay \& Ang, Chee Siang \& Deravi, Farzin 2019. Understanding Conspiracy Theories. Advances in Political Psychology 40, Suppl. 1, lk 3-35 (doi: 10.1111/pops.12568).

Event 201 = Event 201. A Global Pandemic Exercise (http://www.centerforhealthsecurity. org/event201 - 30. märts 2020).

Goldstein, Diane E. 2004. Once upon a Virus. AIDS Legends and Vernacular Risk Perception. Logan: Utah State University Press.

Hiiemäe, Reet 1997. Eesti katkupärimus. Monumenta Estoniae Antiquae II. Eesti Muistendid. Mütoloogilised haigused I. Tartu: Eesti Keele Instituut ja Eesti Kirjandusmuuseum.

Hiiemäe, Reet 1999. Katk ja aids - sarnaste fenomenide käsitlemine rahvapärimuses. Kuuldust-nähtust. Tänapäeva folkloorist 4. Tartu: Eesti Kirjandusmuuseum, lk 31-44 (http://www.folklore.ee/pubte/kuuldust/031Katkjaaids.html - 31. märts 2020).

Keck, Frédéric \& Lachenal, Guillaume 2019. Simulations of epidemics: techniques of global health and neo-liberal government. Kelly, A. H. \& Keck, F. \& Lynteris, Ch. (toim). The Anthropology of epidemics. Oxon \& New York: Routledge, lk 25-42.

Kharel, Gopi Chandra 2014. Ebola is CIA-Created Demon? Cospiracy Theory Goes Viral as Meme Shows Disease Created by 'White People'. International Busines Times (https:// www.ibtimes.co.in/ebola-cia-created-demon-conspiracy-theory-goes-viral-meme-showsdisease-created-by-white-people-609490 - 30. märts 2020).

Kõiva, Mare 2010. Patsiendinarratiivid Internetis. Paal, Piret (toim). Inimene, tervis ja haigused. Tänapäeva folkloorist 9. Tartu: EKM Teaduskirjastus, lk 217-251.

Kõiva, Mare 2014. Inter-patient Narratives in the Internet. Kõiva, Mare. Through the Ages. Time, Space and Eternity. Sator 13. Tartu: Eesti Kirjandusmuuseumi Teaduskirjastus, lk 183-208 (http://www.folklore.ee/rl/pubte/ee/sator/sator13/-31. märts 2020).

Lee, Jon D. 2014. An Epidemic of Rumors. How Stories Shape Our Perceptions of Disease. Utah State University Press.

McNeill, Lynne S. 2018. "My friend posted it and that's good enough for me!": Source Perception in Online Information Sharing. Journal of American Folklore 131 (522), lk 493-499 (doi: 10.5406/jamerfolk.131.522.0493).

Michelmore, Karen \& Parish, Rebecca \& O'Connor, Kendall 2020.Christmas Island locals surprised, split over quarantine of Australians from coronavirus epicentre. $A B C$ News, 29. jaanuar (https://www.abc.net.au/news/2020-01-29/christmas-island-locals-onquarantine-for-coronavirus/11910326 - 31. märts 2020).

Paganini, Pierluigi 2020. New Cyber Attack Campaign Leverages the COVID. Infodemic. Affairs, 26. veebruar (https://securityaffairs.co/wordpress/98484/malware/covid-19hacking-campaign.htm - 31. märts 2020).

Shifman, Limor 2014. Memes in Digital Culture. Cambridge, MA: MIT Press. 
Shifman, Limor \& Levy, Hadar \& Thelwall, Mike 2014. Internet Jokes: The Secret Agents of Globalization? Journal of Computer-Mediated Communication 19, lk 727-743 (doi: 10.1111/jec4.12082).

Tavast, Johannes 2020 [1931]. Jüri kihelkond. Ajaloolist traditsiooni kogunud Jürist 1931. a. suvel Johannes Tavast. EKLA F. 199, M 54. Tartu: EKM Teaduskirjastus (http:// folklore.ee/pubte/ajaloolist/jyr - 26. märts 2020).

The Guardian 2020 = Britons returning from China to be 'safely isolated' for 14 days, says Hancock - as it happened. The Guardian, 29. jaanuar (https://www.theguardian. com/world/live/2020/jan/29/coronavirus-live-updates-china-wuhan-death-toll-casessymptoms-treatment-evacuation-us-japanese-citizens-latest-news?page=with:block5e317d8b8f08e133247390a5 - 31. märts 2020).

The Local 2020 = China demands apology over Danish newspaper's cartoon flag 'insult'. The Local, 28. jaanuar (https://www.thelocal.dk/20200128/china-demands-apology-overdanish-newspapers-cartoon-flag-insult - 30. märts 2020).

Voolaid, Piret 2014. Olümpiavõitja kui rahvuskangelane: folkloristlik vaade ühele dopingujuhtumile. Mäetagused 58, lk 53-84 (doi: 10.7592/MT2014.58.voolaid).

Xiong, Yong \& Gan, Nectar $2020=$ This Chine(se doctor tried to save lives, but was silenced. Now he has coronavirus. CNN, 4. veebruar (https://edition.cnn.com/2020/02/03/ asia/coronavirus-doctor-whistle-blower-intl-hnk/index.html - 30. märts 2020).

\section{Summary}

\section{Responses to the initial phase of SARS-CoV-2 in the (social) media}

\section{Maris Kuperjanov}

Archivist-referent, Department of Folkloristics

Estonian Literary Museum, Estonia

maris.kuperjanov@folklore.ee

Keywords: conspiracy theories, coronavirus, internet memes, public health, social media

The aim of the article is to give an overview of the first month of the novel coronavirus outbreak and public reactions to the news in the media comments and social media environments. The pandemic is still in its initial phase at the time of the publishing of the article and the knowledge about virus SARS-CoV-2 and disease COVID-19 is increasing on a daily basis. During the first month of the virus outbreak the growing flow of information and rapid escalation of the situation made the topic more noticeable in both the media and social media and thus provided a fertile basis for jokes and internet memes, legends, fake news, misinformation and conspiracy theories, etc., as was the case with the former bigger epidemics and pandemics. As it has also been observed previously, the consequences of some fake news, misinformation and conspiracy theories may often be more harmful for the society than the disease itself. Several motives 
and storylines are universal and surge as similar situations arise both in Estonia and in the rest of the world.

The article also presents a small selection of more prominent topics and examples of the outbreak from social media environments during the initial phase of international awareness of the novel coronavirus.

Maris Kuperjanov on Eesti Kirjandusmuuseumi folkloristika osakonna arhivaar-referent, haldab osakonna teadusarhiivi EFITA. Varasemalt on ta pikka aega töötanud folkloristika osakonnas assistendi ja toimetajana, tegelenud Eesti Kirjandusmuuseumi Teaduskirjastuses folkloristikaalaste väljaannete ettevalmistamisega, kuulunud ajakirjade Folklore: An Electronic Journal of Folklore ja Mäetagused toimetusse. Lisaks on ta töötanud ka kliiniliste uuringute valdkonnas.

Maris Kuperjanov works as an archivist-referent at the Department of Folkloristics of the Estonian Literary Museum, administrating the department's research archive. She formerly worked at the Department of Folkloristics as an assistant and editor, and at the Estonian Literary Museum Scholarly Press, performing pre-press activities for folkloristic publications, among others for the journals Folklore: An Electronic Journal of Folklore and Mäetagused. She has also worked in the field of clinical research.

maris.kuperjanov@folklore.ee 